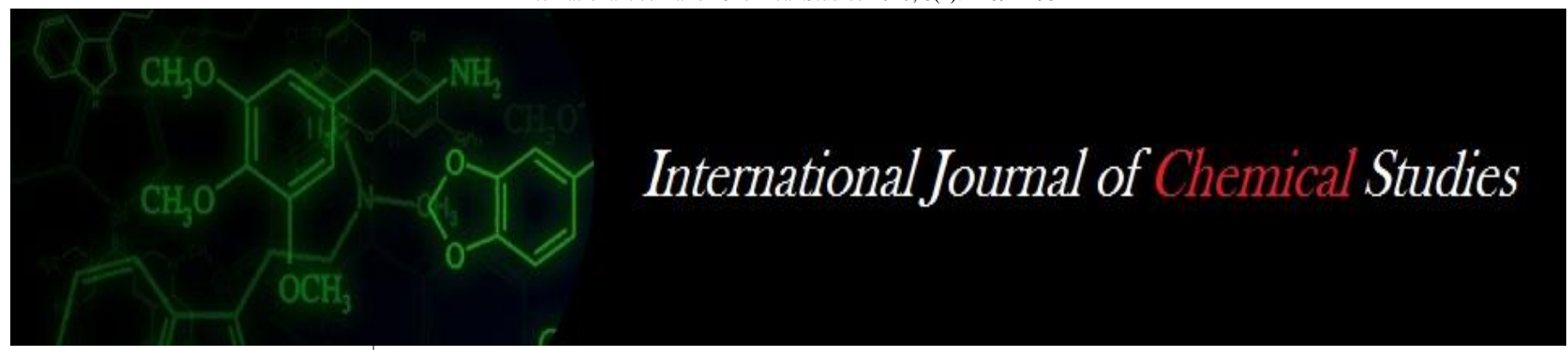

P-ISSN: 2349-8528

E-ISSN: 2321-4902

www.chemijournal.com

IJCS 2020; 8(4): 1289-1295

(C) 2020 IJCS

Received: 22-06-2020

Accepted: 25-06-2020

\section{Bhuneshwar Verma}

College of Agriculture, Indira

Gandhi Krishi Vishwavidyalaya,

Raipur, Chhattisgarh, India

\section{LK Ramteke}

College of Agriculture, Indira Gandhi Krishi Vishwavidyalaya,

Raipur, Chhattisgarh, India

\section{Shahid}

National Rice Research Institute (NRRI), Cuttack Odisha, India

Sweta Singh

College of Agriculture, Indira Gandhi Krishi Vishwavidyalaya, Raipur, Chhattisgarh, India

\section{Submergence tolerance in relation to some metabolic changes and anti-oxidant enzyme activities of submerged rice (Oryza sativa $\mathbf{L}$.)}

\author{
Bhuneshwar Verma, LK Ramteke, M Shahid and Sweta Singh
}

DOI: https://doi.org/10.22271/chemi.2020.v8.i4k.9782

\begin{abstract}
The experiment was conducted to find out the effect of plant spacing $(15 \times 10$ and $20 \times 15 \mathrm{~cm})$ with two varieties i.e. IR64 (submergence susceptible) and IR64-Sub1 (submergence tolerant) under conventional and submerged condition at the National Rice Research Institute (NRRI),Cuttack Odisha during the Rabi season of 2018. Different planting densities were maintained using different spacing's. These include $\left(\mathrm{S}_{1}\right)$ $15 \mathrm{~cm} \times 10 \mathrm{~cm},\left(\mathrm{~S}_{2}\right) 15 \mathrm{~cm} \times 20 \mathrm{~cm}$. The experiment was laid out in a randomized complete block design with 3 replications. Spacing of $15 \mathrm{~cm} \times 10 \mathrm{~cm}$ has maximum survival rate in submerged condition on IR64-Sub1 rice cultivar, this result suggests that higher planting density $(15 \mathrm{~cm} \times 10 \mathrm{~cm})$ rather than increased number of seedling hill ${ }^{-1}$ is necessary for getting higher yield of IR-64Sub1 rice cultivar in continuous submerged condition. (Where $V_{1}=I R 64, V_{2}=I R-64 S u b 1, S_{1}=15 \mathrm{~cm} \times 10 \mathrm{~cm}, S_{2}=20 \mathrm{~cm} \times 15 \mathrm{~cm}$ ).
\end{abstract}

Keywords: Antioxidant enzyme, Chlorophyll, elongation, Turbidity, V1 (IR-64), V2 (IR-64 Sub 1), (Sub1) Submergence tolerance, Flash floods SOD (Super oxide dismutase), CAT (Catalase), Peroxidase, root exudates, DAT (Days after transplanting)

\section{Introduction}

Rice is a semi-aquatic plant that is cultivated under partially flooded conditions. However, flash flooding can cover the entire plant for prolonged periods, and most rice cultivars die within 7 days of complete submergence (Xu et al. 2006; Bailey-Serres et al. 2010) ${ }^{[22,1]}$. These conditions prevailed for rice cultivated in flood-prone areas of South-east Asia. The erratic rainfall patterns and increasing risks from typhoon and rainfall- induced flood in these areas, seriously affects crop establishment and survival. It imposes a complex abiotic stress in floodprone ecosystem, because it substantially reduces crop stand, especially if it occurs during early vegetative stage and prolongs for more than a week (Bailey-Serres et al. 2010) ${ }^{[1]}$. The extent of damage and plant survival due to complete submergence during the vegetative stage is largely modulated by genotype and pretreatments (Ling et al. 2004) ${ }^{[7]}$, with higher temperatures, water turbidity (Das et al. 2009) ${ }^{[5]}$, lower solar radiation worsening the severity of the stress, low light, limited gas diffusion, effusion of soil nutrients (Ram et al. 1999) ${ }^{[15]}$, and accumulation of ethylene.

Intolerant cultivars showed greater responses to submergence and developed visual damages (chlorosis, leaf senescence and elongation) under aerobic conditions after de-submergence (Gautam et al. 2014).

Flooding and re-aeration can induce oxidative stress, causing an increased production of reactive oxygen species (ROS) High levels of antioxidant enzymes including catalase (CAT), superoxide dismutase (SOD) and peroxidase (PER) are important for the survival under oxidative stress of many plants such as rice (Ella et al. 2003). The response that is frequently observed in rice plants under complete submergence was shoot elongation, adverse effect of which is an increase in carbohydrate consumption for cell division, cell elongation and leaf elongation maintenance (Setter \& Laureles, 1996 and Voesenek et al., 2006) ${ }^{[21]}$. Adoption of submergence tolerant varieties is a major management strategy for improving rice yield under short term (10-15 days) submerged condition. Rice varieties that exhibit limited or no elongation during complete submergence often show tolerance to flash flooding, whereas deepwater rice varieties adopt opposite strategy, displaying greater elongation of leaf and culm (Luo et al., 2011) ${ }^{[8]}$.
Corresponding Author: Bhuneshwar Verma College of Agriculture, Indira Gandhi Krishi Vishwavidyalaya, Raipur, Chhattisgarh, India 
These two strategies (i.e. quiescence and escape) are quite useful to counteract the adverse effect of flash and deepwater flooding, respectively. It was reported that introgression of submergence tolerance (Sub1) its survival under complete submergence through quiescence mechanism (Neeraja et al., 2007) ${ }^{[12]}$. Using the Sub1, several submergence tolerant mega rice varieties, IR64Sub-1, have been developed and are being released for commercial cultivation in Asia and Africa (Sarkar et al., 2009 a; Singh et al., 2009; ${ }^{[17,20]}$ The mega varieties with Sub1 survive flash flooding through quiescence strategy. The strategy is no longer useful if water stagnate more than 2-3 weeks (Sarkar et al., 2006) ${ }^{[19]}$. Under complete submergence, photosynthesis is weakened, and plants exhaust the reserve carbohydrate and ultimately die (Das et al., 2005, 2009; Sarkar and Panda, 2009) [6, 17]. To continue life, exposure of leaf tip above the water surface is vital even for submergence tolerant varieties if flooding duration exceeds more than 2-3 weeks (Colmer and Voesenek, 2009; BaileySerres and Sarkar and Bhattacharjee, 2012; Colmer et al., 2014) ${ }^{[18,4]}$. There exists vast possibility for increasing rice production and harnessing the productivity potentials of submergence-affected areas with the use of submergencetolerant varieties, particularly when combined with best nutrient management practices specific for these areas.

\section{Methods and Materials \\ Experimental setup}

The experiment was conducted under natural conditions during the Rabi season (Feb-May) of 2018 at experimental farm of ICAR-National Rice Research Institute (NRRI) Cuttack, India with two rice (Oryza sativa L.) cultivars i.e. IR64- Sub1 having submergence tolerant Sub-1 gene and IR-64 without Sub-1 gene. Crops were grown under two different condition i.e. submerged condition and normal condition with a common dose of N: P: K fertilizer @ 80:40:40 kg ha-1.

\section{Plant material and growth conditions}

The study site was on the experimental farm of the ICARNational Rice Research Institute, Cuttack, India $\left(20^{\circ} 25^{\prime} \mathrm{N}\right.$, $85^{\circ} 55^{\prime}$, elevation $24 \mathrm{~m}$ above mean sea level). The surface elevation of the study area varies from 19-20 m above mean sea level at the center and from $44 \mathrm{~m}$ on the south to $26 \mathrm{~m}$ on the north. Underlying surface of the city is composed of unconsolidated alluvium in alternating sequences of sand, silt, clay, the depth of which continues down to $120 \mathrm{~m}$.

Plants were irrigated with fresh water to maintain $2 \mathrm{~cm}$ standing water except during the period when rice plants were subjected to submergence. The plants were submerged at maximum tillering stage in a concrete tank filled with clear and turbid water and the water depth was maintained at $70 \mathrm{~cm}$ above the top of the plant canopy for 15 days. The experiment was arranged in a factorial randomized block design with three replications. After de-submergence, the plants were allowed to recover for 7 days, and plant survival was recorded. Plant samples were collected $48 \mathrm{~h}$ before submergence and then 7 days after de-submergence for various measurements.

\section{Water quality parameters}

Water temperature, dissolved oxygen (DO), $\mathrm{pH}$, electrical conductivity (EC), redox potential (ORP), total dissolved salts (TDS) were determined. Whereas temperature and other water quality parameters were determined by using U-50 multiparameter water quality meter (HORIBA, Kyoto, Japan).

\section{Plant survival}

Plant survival was determined by counting the number of plants that were able to produce at least one new leaf after 7 days of de-submergence and was expressed as percentage of the initial number before submergence.

\section{Chlorophyll content}

Chlorophyll concentration was determined before and after submergence colourimetrically following the procedure by Porra (2002). Chopped fresh leaf tissue of $0.1 \mathrm{~g}$ was transferred to a capped measuring tube containing $25 \mathrm{~mL}$ of $80 \%$ acetone, and kept inside a refrigerator $\left(4^{\circ} \mathrm{C}\right)$ for $48 \mathrm{~h}$ before measurements were made using a spectrophotometer (SICAN 2301 double beam spectrophotometer, Incarp Instruments, Hyderabad, India). Chl $a$ and $\mathrm{Chl} b$ concentrations were calculated using the following equations:

$$
\begin{aligned}
& \text { Chlorophyll a }\left(m g g^{-1} \text { tissue }\right)=12.7\left(\mathrm{~A}_{663}\right)-2.69\left(\mathrm{~A}_{645}\right) \times \frac{\mathrm{V}}{1000 \times \mathrm{W}} \\
& \text { Chlorophyll } \mathrm{b}\left(\mathrm{mg}^{-1} \text { tissue }\right)=22.9\left(\mathrm{~A}_{645}\right)-4.68\left(\mathrm{~A}_{663}\right) \times \frac{\mathrm{V}}{1000 \times \mathrm{W}} \\
& \text { Total Chlorophyll }\left(\mathrm{mg} \mathrm{g}^{-1} \text { tissue }\right)=20.2\left(\mathrm{~A}_{645}\right)+8.02\left(\mathrm{~A}_{663}\right) \times \frac{\mathrm{v}}{1000 \times \mathrm{W}}
\end{aligned}
$$

$A=$ Absorbance at specific wave length

$\mathrm{V}=$ Final volume of chlorophyll extract in $80 \%$ acetone $\mathrm{W}=$ Fresh weight of the tissue extracted

\section{Catalase}

Catalase enzyme activity was measured following the method of Beers and Sizer (1952). Take fresh leaf tissue 0.15g sample and homogenize in it $2 \mathrm{ml}$ of cold potassium phosphate buffer $(0.05 \mathrm{M}, \mathrm{pH} 7)$ with a pinch of sand centrifuge at $14000 \mathrm{rpm}$ for $20 \mathrm{~min}$ at $4^{\circ} \mathrm{C}$ and collect the supernatant solution for using enzyme analysis, take reagent mixture $3 \mathrm{ml}$ consisting of 1.9 ml double D.W., $1 \mathrm{ml} 0.059 \mathrm{M} \mathrm{H}_{2} \mathrm{O}_{2}$ solution and $0.1 \mathrm{ml}$ diluted enzyme extract, incubated in spectrophotometer.

\section{Peroxidase}

Peroxidase activity was measured following the method of Hammerschmidt el al., (1982). Take fresh leaf tissue $0.15 \mathrm{~g}$ sample and homogenize in it $2 \mathrm{ml}$ of cold potassium phosphate buffer $(50 \mathrm{mM}, \mathrm{pH} 7)$ with a pinch of sand centrifuge at 14000 rpm for $20 \mathrm{~min}$ at $4^{\circ} \mathrm{C}$ and collect the supernatant solution for using enzyme analysis take the assay mixture containing 0.45 $\mathrm{ml}$ of $0.1 \mathrm{M}$ phosphate buffer, $0.75 \mathrm{ml}$ of buffer containing guaiacol, $0.25 \mathrm{ml}$ of $\mathrm{H}_{2} \mathrm{O}_{2}$ solution $50 \mu \mathrm{l}$ of crude enzyme extract the total reaction volume will be $1.5 \mathrm{ml}$ measure the rate of change in absorbance at $420 \mathrm{mn}$ by spectrophotometer.

\section{Superoxide dismutase (SOD)}

SOD activity was measured following the method of Dhindsa et al.,(1981)Take fresh leaf tissue $0.15 \mathrm{~g}$ sample and homogenize in it $2 \mathrm{ml}$ of cold phosphate buffer $(0.05 \mathrm{M}, \mathrm{pH}$ 7.8) with a pinch of sand centrifuge at $10000 \mathrm{rpm}$ for $20 \mathrm{~min}$ at $4^{\circ} \mathrm{C}$ and collect the supernatant solution for using enzyme analysis, take aliquot of $0.1 \mathrm{ml}$ enzyme extract and place in transparent glass tube add $4.9 \mathrm{ml}$ phosphate buffer $(50 \mathrm{mM}$, $\mathrm{pH}$ 7.8) $\mu \mathrm{M}$ riboflavin, $4.3 \mathrm{~m} M$ TEMED, $0.112 \mathrm{~m} M$ NBT and $0.1 \mathrm{~m} M$ EDTA. Prepare the blank by adding $0.1 \mathrm{ml}$ denatured extract and $4.9 \mathrm{ml}$ reaction buffer in a complete opaque test tube, as blank in another two test tube, one transparent and one opaque, add $0.1 \mathrm{ml}$ extract buffer and $4.9 \mathrm{ml}$ reaction buffer, the reaction will be being on exposing the sample to 
light and left to run for exactly 15 min after the completion of reaction, measure the absorbance in each sample at $560 \mathrm{~nm}$.

\section{Result and discussion \\ Plant parameters \\ 1. Chlorophyll}

Chlorophyll content at panicle initiation stage the chlorophyll A was presented in the Fig 1. It was found that chlorophyll A under flash flooding condition was $3.6 \mathrm{mg}$ g -1 fresh weight which was significantly higher than conventional condition (2.6 mg g-1 fresh weight).

It was recorded that chlorophyll A under spacing S2 was 3.4 mg g -1 fresh weight which was significantly higher than chlorophyll under spacing S1 (2.8 mg g-1 fresh weight).

Among varieties, there was no significant difference in the chlorophyll and it was recorded to be $3 \mathrm{mg} \mathrm{g}^{-1}$ fresh weight under V1 and $3.2 \mathrm{mg} \mathrm{g}^{-1}$ fresh weight under V2. A significant difference was observed between the interaction of moisture and spacing and interaction of moisture, variety and spacing. The chlorophyll B under flash flooding condition was $1.6 \mathrm{mg}$ $g^{-1}$ fresh weight which was significantly higher than conventional condition (1.0 $\mathrm{mg} \mathrm{g}^{-1}$ fresh weight). It was recorded that chlorophyll B under spacing S2 was $1.4 \mathrm{mg}^{-1}$ fresh weight which was significantly higher than chlorophyll B under spacing S1 (1.2 $\mathrm{mg}^{-1}$ fresh weight). Among varieties, chlorophyll B under variety $\mathrm{V} 2$ was $1.7 \mathrm{mg}^{-1}$ fresh weight which was significantly higher than chlorophyll B under V1 (0.9 $\mathrm{mg}^{-1}$ fresh weight). A significant difference was observed between the interaction of moisture and variety and interaction of moisture, variety and spacing. The total chlorophyll was presented in the Table 4.18. It was found that chlorophyll under flash flooding condition was 5.5 mg g-1 fresh weight which was significantly higher than conventional condition (4.0 $\mathrm{mg}^{-1}$ fresh weight).It was recorded that total chlorophyll under spacing S2 was $5.1 \mathrm{mg} g$ $-I$ fresh weight which was significantly higher than total chlorophyll under spacing $\mathrm{S} 1 \quad\left(\begin{array}{llllll}4.3 & \mathrm{mg} & g^{-1} & \text { fresh }\end{array}\right.$ weight).Among varieties, there was no significant difference in the chlorophyll and it was recorded to be $4.3 \mathrm{mg} \mathrm{g}^{-1}$ fresh weight under V1 and $5.2 \mathrm{mg} \mathrm{g}^{-1}$ fresh weight under V2. A significant difference was observed between the interaction of moisture and variety and interaction of moisture, variety and spacing. Leaves plays vital role in the process of photosynthesis, thus having direct influence on grain production. In the present investigation, total chlorophyll content was increased from panicle initiation stage in flash flooded condition. Pramanik et al. (2013) ${ }^{[13]}$ and Bashir et al., (2010) ${ }^{[2]}$ also reported the similar result. Among the spacing maximum chlorophyll content was observed in spacing $20 \times 15 \mathrm{~cm}\left(5.14 \mathrm{mg}^{-1}\right.$ fresh weight) than other spacing because wider spacing had shown superior performance in respect of all morpho-physiological characters. Similar results were observed by Mondal et al. (2013) [9]. Chlorophyll content increases with increasing spacing. Interaction of moisture and spacing, moisture and variety had significant difference on chlorophyll content. Pramod Kumar (2002) studied photosynthetic and yield performance of 15 genotypes of rice under low temperature condition in hills and found the significant differences in content of photosynthetic pigment (chl. A, chl. B, total chl.) Amongst the genotypes under both normal and late planting and under low temperature condition.

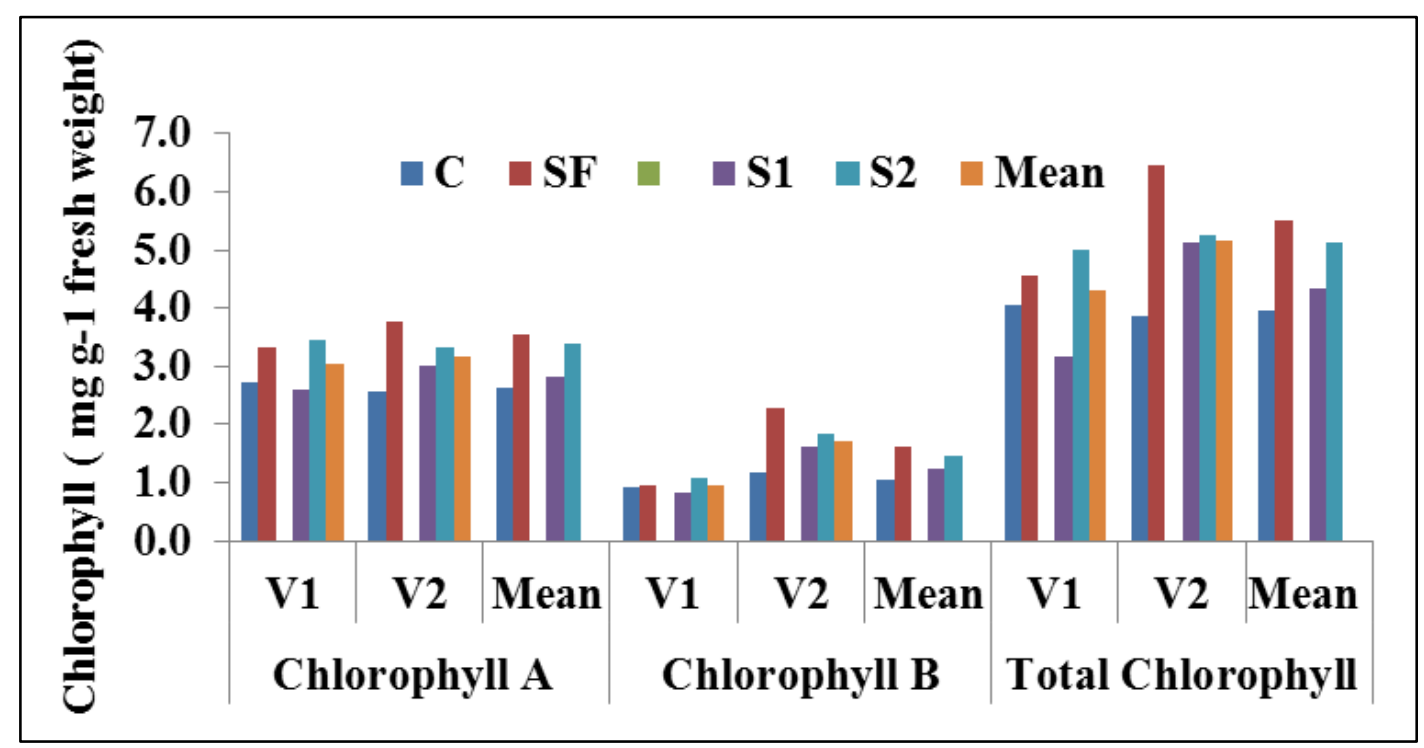

Fig 1: Chlorophyll content in relation to conventional and stagnant flooding under two plant spacing at three growth stages of two varieties of rice. $(\mathrm{S} 1=15 \times 10 \mathrm{~cm} ; \mathrm{S} 2=20 \times 15 \mathrm{~cm} ; \mathrm{V} 1=\mathrm{IR} 64 ; \mathrm{V} 2=\mathrm{IR} 64-\mathrm{Sub} 1, \mathrm{C}=$ Conventional, $\mathrm{SF}=$ Stagnant flooded $)(\mathrm{CD}(\mathrm{P}<0.05) \mathrm{M}=0.33 ; \mathrm{S}=0.33 ; \mathrm{V}=$ $0.5 ; \mathrm{MxS}=\mathrm{NS} ; \mathrm{MxV}=\mathrm{NS} ; \mathrm{SxV}=\mathrm{NS}$ )

\section{Plant Enzymes}

\section{Superoxide dismutase (SOD)}

The SOD content during stress stage of the rice plant was analyzed and presented in Fig. 2 Enzyme activities have been affected drastically by submergence treatment. The SOD activity in leaves of rice genotypes increased significantly under flash flooding condition. It was found that SOD activity under flash flooding condition was 122.2 unit g-1 which was significantly higher than conventional condition (112.4 unit $\mathrm{g}$ $\left.{ }^{1}\right)$. It was recorded that SOD activity under spacing S1 was 122.5 unit $\mathrm{g}-1$ which was significantly higher than SOD activity under spacing S2 (112.1 unit $\left.\mathrm{g}^{-1}\right)$. Among varieties, SOD activity under variety V2 was 127.2 unit $\mathrm{g}^{-1}$ which was significantly higher than SOD under variety V1 (107.3 unit g${ }^{1}$ ). A significant difference was observed between the interaction of moisture and variety and interaction of moisture, variety and spacing. Similar finding was reported by Monak et al., (1987) and Larson (1988) who reported that the SOD activity was increased in Sub1 cultivars. It was found that the SOD activity of the plant increased with increase in submergence treatment. 


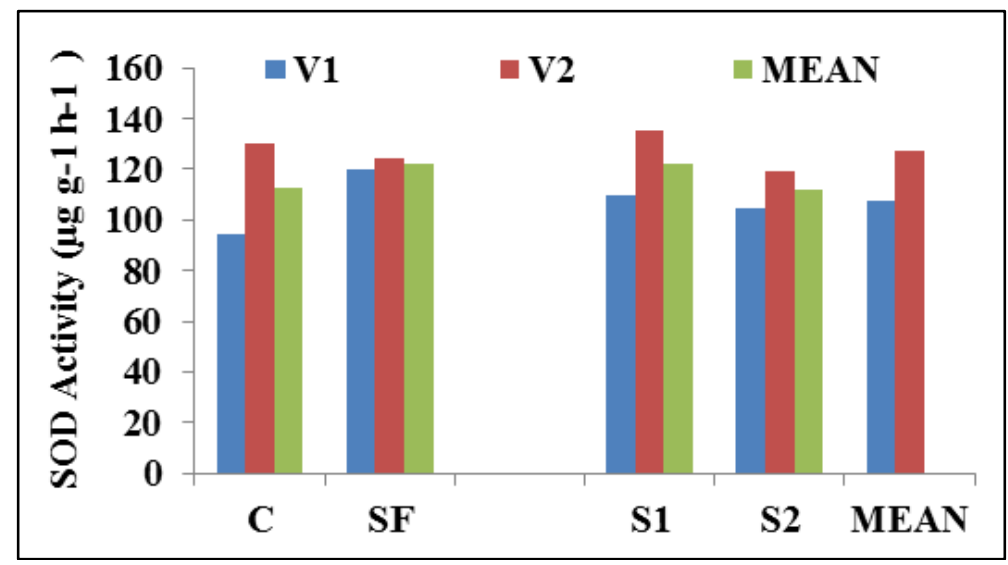

Fig.2: SOD Activity was observed under conventional and stagnant flooded conditions. (S1=15x10cm; S2=20x15; V1=IR 64; V2=IR 64 Sub-1 $(\mathrm{CD}(\mathrm{P}<0.05) \mathrm{M}=6.9, \mathrm{~S}=6.9, \mathrm{~V}=6.9, \mathrm{M} x \mathrm{~S}=\mathrm{NS}, \mathrm{M} \times \mathrm{V}=9.8, \mathrm{~S} \times \mathrm{V}=\mathrm{NS}, \mathrm{MxSxV}=13$.

\section{Catalase}

The catalase content at stress stage of the rice plant was analyzed and presented in Fig 3._Catalase activity in leaves of rice genotypes increased significantly with increasing levels of submergence. It was found that catalase activity under flash flooding condition was 24.3 unit g-1 which was significantly higher than conventional condition $\left(17.1\right.$ unit $\left.\mathrm{g}^{-1}\right)$. It was recorded that catalase activity under spacing $\mathrm{S} 1$ was 21.9 unit $\mathrm{g}^{-1}$ which was significantly higher than catalase activity under spacing S2 (19.5 unit $\mathrm{g}^{-1}$ ). Among varieties, catalase activity under variety $\mathrm{V} 2$ was 22.9 unit $\mathrm{g}^{-1}$ which was significantly higher than catalase activity under variety V1 (18.5unit $\left.\mathrm{g}^{-1}\right)$. A significant difference was observed between the interaction of moisture and variety and interaction of moisture, variety and spacing. Similar finding was reported by Monk et al. (1987) [10] who found that catalase activity have been affected drastically by submergence treatment. Catalase activity in leaves of rice genotypes increased significantly with increasing levels of submergence. The level of increase in catalase activity during submergence was roughly 4-6 folds in susceptible and 6 folds in tolerant genotypes over non submerged controls.

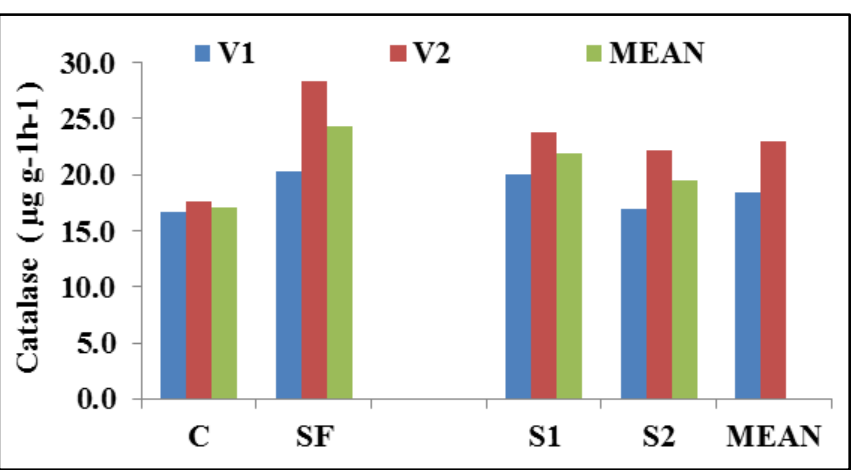

Fig 3: Catalase Activity was observed under conventional and stagnant flooding conditions. ( $\mathrm{S} 1=15 \times 10 \mathrm{~cm} ; \mathrm{S} 2=20 \times 15 \mathrm{~cm} ; \mathrm{V} 1=\mathrm{IR}$ 64; V2= IR 64-Sub1, $(\mathrm{CD}(\mathrm{P}<0.05) \mathrm{M}=1.4, \mathrm{~S}=1.4, \mathrm{~V}=1.4, \mathrm{M} \times \mathrm{S}=$ $\mathrm{NS}, \mathrm{M} x \mathrm{~V}=2.0, \mathrm{~S} \times \mathrm{V}=\mathrm{NS}, \mathrm{MxSxV}=2.8$ )

\section{Peroxidase}

The Peroxidase activity of the rice plant during the stress condition was analyzed and presented in Fig: 4. Peroxidase activity in leaves of rice genotypes increased significantly with increasing levels of submergence. Peroxidase activity increased for IR64-Sub1 during 10 days submergence of period. It was found that Peroxidase activity under flash flooding condition was 21.4 unit $\mathrm{g}^{-1}$ which were significantly higher than conventional condition (19.3 unit $\left.\mathrm{g}^{-1}\right)$. Peroxidase activity didn't differ significantly with the plant spacing and it ranged from 20 unit $\mathrm{g}-1$ under $\mathrm{S} 1$ to 20.7 unit $\mathrm{g}^{-1}$ under S2. Among varieties, peroxide activity under variety V2 was 21.7 unit $\mathrm{g}^{-1}$ which was significantly higher than the Peroxidase activity under variety V1 (19 unit $\left.\mathrm{g}^{-1}\right)$. A significant difference was observed between the interaction of moisture and variety, spacing and variety, interaction of moisture, variety and spacing. Similar finding was reported by Monk et al. (1987) ${ }^{[10]}$ who found that variable activity of Peroxidase tolerant and susceptible cultivars.

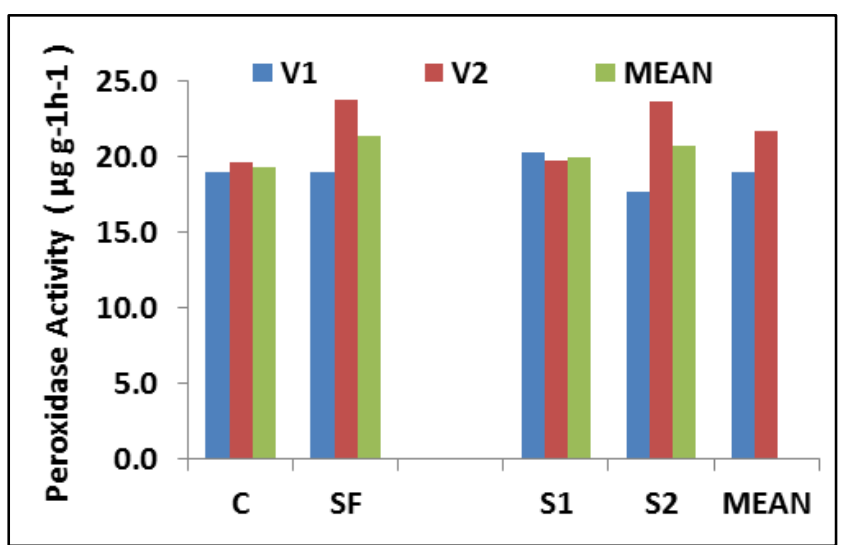

Fig 4: Peroxidase Activity was observed under conventional and stagnant flooded conditions. ( $\mathrm{S} 1=15 \times 10 \mathrm{~cm} ; \mathrm{S} 2=20 \times 15 \mathrm{~cm}$; V1=IR 64; V2= IR 64-Sub1) $(\mathrm{CD}(\mathrm{P}<0.05) \mathrm{M}=1.4 ; \mathrm{S}=\mathrm{NS} ; \mathrm{V}=1.4$; $\mathrm{MxS}=\mathrm{NS} ; \mathrm{MxV}=2 ; \mathrm{SxV}=2 ; \mathrm{MxSxV}=2.8$ )

\section{Survival Rate}

Survival rate was analyzed under flash flooding condition. The survival rate under conventional condition was taken as $100 \%$. Under flash flooding condition during 10 days treatment water level was maintained at $70-75 \mathrm{~cm}$ in submergence tank. Seven days after desubmergence, the newly emerged leaves were counted and data is presented in Table 1. It was observed that the variety V2 showed higher survival rate under the spacing $\mathrm{S} 1$ and lowest survival rate was recorded for variety V1 under the spacing S2.

Table 1: Survival rate of plant after seven days release the submergence treatment.

\begin{tabular}{|c|c|c|}
\hline Treatment & After 7 days & After 14 days \\
\hline V1S1 & 32.19 & 75.31 \\
\hline V1S2 & 27.08 & 62.08 \\
\hline V2S1 & 55.83 & 76.67 \\
\hline V2S2 & 48.33 & 75.25 \\
\hline
\end{tabular}


Table 2: Change the plant height before and 15 days after submergence treatment.

\begin{tabular}{|c|c|c|}
\hline \multicolumn{3}{|c|}{ Plant Height (in cm) } \\
\hline Treatment & Before submergence & 15 days after submergence \\
\hline V1S1 & 32.4 & 61.0 \\
\hline V1S2 & 29.5 & 65.9 \\
\hline V2S1 & 33.8 & 56.9 \\
\hline V2S2 & 31.8 & 52.7 \\
\hline
\end{tabular}

(S1=15x10 cm; S2=20x15 cm; V1=IR 64; V2=IR 64-Sub1

Similar finding was reported by Sarkar and Bhattacharjee, (2011) who found that plant height did not increase much in sub1 cultivars, resulted significantly lower elongation compared to other genotypes

\section{SPAD Reading}

The SPAD readings were recorded at different growth stages of the rice plant and presented in the Fig: 5. it was observed that the SPAD reading increased gradually with each advancing stage. The mean SPAD reading at active tillering stage (30 DAT) recorded under conventional condition was 32.4 which was significantly higher than under flash flooded condition (28.22). The SPAD reading didn't differ significantly with the plant spacing and it ranged from 30.2 in $\mathrm{S} 2$ to 30.3 in $\mathrm{S} 1$. Among varieties, there was no significant difference in the SPAD reading and it was recorded to be 29.7 under $\mathrm{V} 1$ and 30.9 under V2. At 60 DAT SPAD reading recorded under conventional condition was 32 which was significantly higher than under flash flooded condition (30.7). The SPAD reading didn't differ significantly with the plant spacing and it ranged from 31.1 in S1 to 31.6 in S2.Among varieties, there was no significant difference in the SPAD reading and it was recorded to be 31 under $\mathrm{V} 1$ and 31.6under V2. At 90 DAT SPAD reading recorded under flash flooded condition was 32.5 which was significantly higher than conventional condition (29.2). The SPAD reading didn't differ significantly with the plant spacing and it ranged from 30.5 in S2 to 31.2 in S1. Among varieties, there was no significant difference in the SPAD reading and it was recorded to be 30.4 under $\mathrm{V} 1$ and 31.5 under V2. At harvesting stage SPAD reading recorded under flash flooded condition was 16.1 which was significantly higher than conventional condition (9.3). The SPAD reading didn't differ significantly with the plant spacing and it ranged from 12.6 in $\mathrm{S} 2$ to 12.9 in $\mathrm{S} 1$. Among varieties, SPAD reading recorded under V1 was 13.6 which was significantly higher than V2 (11.8). A significant difference was observed with the interaction effect moisture and variety $(\mathrm{M} \times \mathrm{V})$ and among moisture, variety and spacing $(\mathrm{M} \times \mathrm{S} \times \mathrm{V})$. Similar results were observed by Prost and Jeuffroy (2007) ${ }^{[14]}$, who reported that good correlation between SPAD indicators and the N nutrition index.

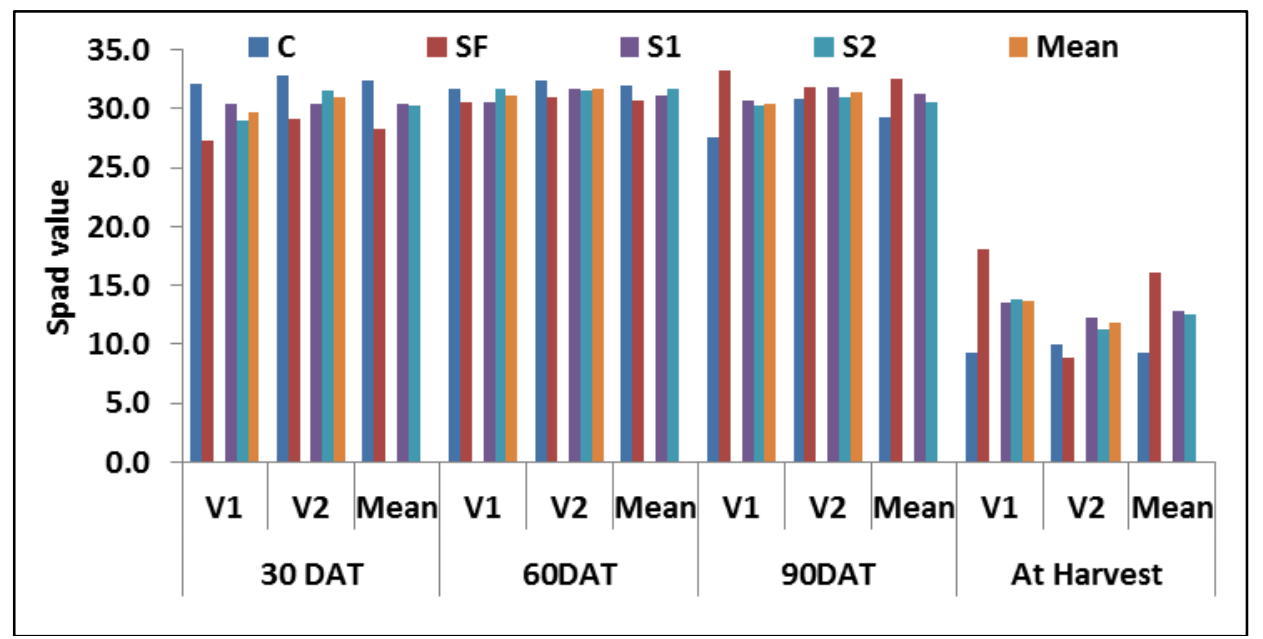

Fig 5: Spad value in relation to conventional and stangnant flooding under two plant spacing at different growth intervals of two varieties of rice. ( $\mathrm{S} 1=15 \times 10 \mathrm{~cm} ; \mathrm{S} 2=20 \times 15 \mathrm{~cm} ; \mathrm{V} 1=\mathrm{IR} 64 ; \mathrm{V} 2=\mathrm{IR}$ 64-Sub1)

\section{Leaf area index (LAI)}

The leaf area index were analyzed at different growth intervals of the rice plant and presented in the Fig 6. It can be revealed that the leaf area index increased gradually with each advancing stage. In a particular stage, the LAI found to significantly under different spacing, variety treatments applied. The mean LAI at active tillering stage (30 DAT) recorded as 0.94 and 0.98 respectively under conventional condition and stagnant flooded condition which were statically at par. LAI was recorded under plant spacing S1 was 1.29 which were significantly higher than the S2 (0.63). Among varieties, there was no significant difference in the LAI and it was recorded to be 0.89 under V1 and 1.02 under $\mathrm{V} 2$. Three factor interaction $(\mathrm{MxSxV})$ was also found to be significant.

At PI stage, (60 DAT), LAI recorded under conventional condition was 2.0 and under stagnant flooded condition was 1.9 which were statically at par. LAI was recorded under plant spacing S1 was 2.5 which was significantly higher than the S2
(1.5). Among varieties, LAI was recorded 2.2 under V1which was significantly higher than the V2 (1.8).

At 90 DAT, LAI was recorded under stagnant flooded condition was 4.8 which was significantly higher than under conventional condition (4.2). LAI recorded under plant spacing S1 was 5.77 which was significantly higher than the S2(3.2). Among varieties, there was no significant difference in the LAI and it was recorded to be 4.64 under V1 and 4.32 under V2. A significant difference was observed with the interaction effect between spacing and variety $(\mathrm{SxV})$ and among moisture, variety and spacing $(\mathrm{MxSxV})$.

At harvest stage, LAI recorded under stagnant flooded condition was 4.3 and found significantly higher than that under conventional condition (3.5). LAI was recorded under plant spacing S1 was 4.8 which was significantly higher than the S2 (3.0). Among varieties, there was no significant difference in the LAI and it was recorded to be 3.8 under V1 and 4.0 under V2. A significant difference was observed with interaction effects of spacing and variety $(\mathrm{SxV})$ and moisture, 
variety and spacing $(\mathrm{MxSxV})$. Similar finding by Yeasmin et al. (2008) [23] who found that leaf area index gradually increased in different growth stage. Spacing S1was recorded significant higher value in conventional and stagnant flooded condition. Maximum LAI under minimum plant spacing was observed Chakrabortty et al. (2014) ${ }^{[3]}$. Watson (1947) defined the LAI as the total leaf area of leaves present per unit land area. Among three spacing, significantly the highest leaf area index was obtained by closer spacing over wider spacing (Sanjeewanie et al., (2011) ${ }^{[16]}$, Moradpour et al. (2013) ${ }^{[11]}$.

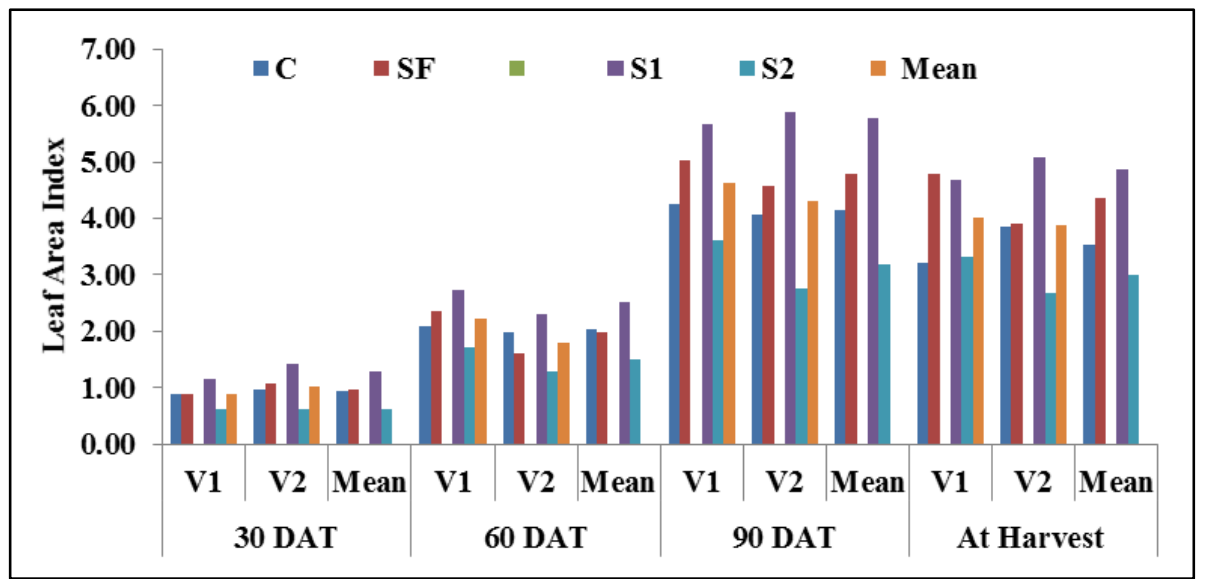

Fig 6: Leaf Area Index in relation to conventional and stangnant flooding under two plant spacing at different growth intervals of two varieties of rice. $(\mathrm{S} 1=15 \times 10 \mathrm{~cm} ; \mathrm{S} 2=20 \times 15 \mathrm{~cm} ; \mathrm{V} 1=\mathrm{IR} 64 ; \mathrm{V} 2=\mathrm{IR} 64-\mathrm{Sub} 1)$

\section{Conclusion}

Results from the present study suggested that stangnant flooding condition was more damaging than conventional condition mainly due some metabolic changes for plants. Stangnant flooding condition decreased the survival and increased the leaf senescence with greater effects on IR64Sub1 cultivars showed higher survival due to close spacing $(\mathrm{S} 1=15 \times 10 \mathrm{~cm})$ by maintaining higher chlorophyll content, Plant density and anti-oxidant enzymes level. Basal P application retained higher concentration of anti-oxidant enzymes after de-submergence which reflected in lower shoot elongation, leaf senescence.

\section{References}

1. Bailey-Serres J, Fukao T, Ronald P, Ismail AM, Heuer S, Mackill D. Submergence tolerant rice: SUB1's journey from landrace to modern cultivar. Rice. 2010; 3:138-147. doi:10.1007/s12284-010-9048-5

2. Bashir MU, Akbar N, Iqbals A, Zaman H. Effectof different sowing dates on yield and yield components of direct seeded coarse rice (OryzaSativaL.) Pak. J. Agri. Sci. 2010; 47(4):361-365.

3. Chakrabortty S, Biswas PK, Roy TS, Mahmud MAA, Mehraj H, Jamal AFM Uddin. Growth and yield of boro rice (BRRI Dhan50) as affected by planting geometry under system of rice intensification. Journal of Bioscience and Agricultural: 19.10.2014, 2014; 2(1):3643.

4. Colmer TD, Armstrong W, Greenway H, Ismail AM, Kirk GJD, Atwell BJ et al. Physiological mechanisms in flooding tolerance of rice: transient complete submergence and prolonged standing water. Progress in Botany. 2014; 75:255-307

5. Das KK, Panda D, Sarkar RK, Reddy JN, Ismail AM, Submergence tolerance in relation to variable floodwater conditions in rice. Environmental and Experimental Botany. 2009; 66:425-434.

6. Das KK, Sarkar RK, Ismail AM. Elongation ability and nonstructural carbohydrate levels in relation to submergence tolerance in rice. Plant Science. 2005; 168:131-136.
7. Ling J, Ming-Yu H, Chun-Ming W, Jian-Min W. Quantitative trait loci and epistatic analysis of seed anoxia germinability in rice (Oryza sativa). Rice Science. 2004; 11:238-244

8. Luo FL, Nagal KA, Scharr H, Zeng B, Schurr U, Matsubara $\mathrm{S}$ et al. Recovery dynamics of growth, photosynthesis and carbohydrate accumulation after desubmergence: a comparison between two wetland plants showing escape and quiescence strategies. Annals of Botany. 2011; 107:49-63.

9. Mondal M, Monjurul A, Adam B Puteh, M Razi Ismail, M Yusop Rafii. Optimizing plant spacing for modern rice varieties, Int. J Agric. Biol. 2013; 15:1.

10. Monk LS, Fagerstedt KV, Crawford RMM. Superoxide dismutase as an aerobic polypeptide a key factor in recovery from oxygen deprivation in Iris pseudocorus Plant Physiology. 1987b; 85:1016-20

11. Moradpour S, Koohi R, Babaei M, Khorshidi MG. Effect of planting date and planting density on rice yield and growth analysis (Fajr variety). Intl J Agri Crop Sci. 2013; 5(3):267-272.

12. Neeraja C, Maghirang-Rodriguez R, Pamplona A, Heuer S, Collard B, Septiningsih E et al. A marker-assisted backcross approach for developing submergencetolerance rice cultivars; Theor. Appl. Genet. 2007; 115:767-776.

13. Pramanik K, Bera AK. Effect of seedling age and nitrogen fertilizer on growth, chlorophyll content, yield and economics of hybrid rice (Oryza sativa L.) International Journal of Agronomy and Plant Production. 2013; 4(S):3489-3499.

14. Prost L, Jeuffroy MH. Replacing the nitrogen nutrition index by the chlorophyll meter to assess wheat $\mathrm{N}$ status. Agron. Sustain. Dev. 2007; 27:321-330.

15. Ram PC, Singh AK, Singh BB, Singh VK, Singh HP, Setter TL et al. Environmental characterization of flood water in eastern India: relevance to submergence tolerance of lowland rice. Experimental Agriculture, 1999.

16. Sanjeewanie GA, Ranamukhaarachchi SL. Study of age of seedlings at transplanting on growth dynamics and 
yield of rice under alternating flooding and suspension of irrigation of water management Recent Research in Science and Technology. 2011; 3(3):76-88. ISSN: 20765061

17. Sarkar RK, Panda D. Distinction and characterization of submergence tolerant and sensitive rice cultivars, probed by the fluorescence OJIP rise kinetics. Func. Plant Biol. 2009; 36:222-233.

18. Sarkar RK, Bhattacharjee B. Rice genotype with SUB1 QTL differ in submergence tolerance, elongation ability during submergence and re-generation growth at re-emergence. Rice, 2012.

19. Sarkar RK, Reddy JN, Sharma SG, Ismail AM. Physiological basis of submergence tolerance in rice and implications for crop improvement. Current Science. 2006; 91:899-906.

20. Singh SP, Mishra NC, Rir-Sima-Ah J, Campen M, Kurup $\mathrm{V}$, Razani-Boroujerdi $\mathrm{S}$ et al. Maternal exposure to secondhand cigarette smoke primes the lung for induction of phosphodiesterase-4D5 isozyme and exacerbated The responses: rolipram attenuates the airway hyperreactivity and muscarinic receptor expression but not lung inflammation and atopy. J Immunol. 2009; 183(3):2115212.

21. Voesenek LACJ, Colmer TD, Pierik R, Millenaar FF, Peeters AJM. How plants cope with complete submergence. New Phytologist. 2006; 170:213-226.

22. Xu K, Xu X, Fukao T, Canlas P, Maghirang-Rodriguez $\mathrm{R}$, Heuer $\mathrm{S}$ et al. Sub1A is an ethylene responsive-factor like gene that confers submergence tolerance to rice. Nature. 2006 442:705-708. doi:10.1038/nature04920

23. Yeasmin MS, Rahman MM, Rahman MS, Ahmad T, Chowdhury AKMMB. Effect of date of transplanting on the growthparameters of boro rice varieties under the systemof rice. Bangladesh. J. Envron. sci. 2008; 14(1):71 -75 .

24. Chidthaisong A, Watanabe I. Changes in concentration and? $13 \mathrm{C}$ values of soil-trapped $\mathrm{CH}_{4}$ and $\mathrm{CO}_{2}$ in flooded rice soil. Biology and Fertility of Soils. 1997; 24:70-75. 